\title{
PENDIRIAN RUMAH BACA DAN PELATIHAN SOFTSKILL UNTUK GURU-GURU SEKOLAH DASAR DI DESA MADOBAK DAN DESA MUARA SIBERUT KEPULAUAN MENTAWAI
}

\author{
Usep Suhud ${ }^{1)}$, Sri Zulaihati' ${ }^{2)}$, Indra Pahala ${ }^{3)}$ \\ Fakultas Ekonomi, Universitas Negeri Jakarta \\ E-mail: usuhud@unj.ac.id
}

\begin{abstract}
Activities devotion the community aims to build a house read in the village madobak and village Muara siberut and training soft skill about science game for school teachers primary and secondary on the island of siberut, the archipelago Mentawai.Although the implementation of the devotion was conducted in June 2009, but this writing has been updated based on the latest data and references so novelty writing is still.The implementation of the devotion performed along with professionals from jakarta.
\end{abstract}

Keywords: mentawai, devotion the community, the house of never so much as read, training soft-skill, teachers

\section{ABSTRAK}

Kegiatan pengabdian masyarakat ini bertujuan untuk mendirikan Rumah Baca di Desa Madobak dan Desa Muara Siberut dan pelatihan softskill tentang science game untuk guru-guru sekolah dasar dan menengah di Pulau Siberut, kepulauan Mentawai. Meskipun pelaksanaan pengabdian ini dilakukan pada Juni 2009, namun tulisan ini telah dimutakhirkan berdasarkan data dan referensi termutakhir sehingga kebaruan tulisan tetap ada. Pelaksanaan pengabdian dilakukan bersama dengan para professional dari Jakarta.

Kata Kunci: Mentawai, pengabdian masyarakat, rumah baca, pelatihan soft-skill, guru

\section{PENDAHULAN}

\section{A. Analisis Situasi}

Kepulauan Mentawai adalah potret kesahajaan. Masyarakat yang masih memegang teguh adat dan dianggap sebagai salah satu suku tertua di dunia (Asdhiana, 2016). Sebagai salah satu kepulauan terluar dari gugusan pulau-pulau di Indonesia dan tertinggal, problem terbesar yang dimiliki oleh kepulauan Mentawai adalah masalah geografis (Candra \& Puspita, 2017). Karena terisolir ini, masyarakat Mentawai mengalami keterbatasan ketika harus mengakses pendidikan, pelayanan kesehatan, unsur pendukung ekonomi, energi, teknologi, dan hasil pembangunan secara umum. Untuk itu, pembangunan infrastruktur di kawasan ini di anggap oleh masyarakatnya sangat mendesak (Candra \& Puspita, 2017).

Masyarakat Mentawai memang sudah sangat mengharapkan perubahan. Mereka pun siap berubah. Ketika penulis mencoba membuat kontak dengan salah seorang dari mereka dan mengutarakan maksud penulis untuk melakukan sebuah kegiatan sosial, dengan antusias tokoh ini mengabari peernya. Pada kontak-kontak berikutnya, penulis sudah mendapatkan gambaran apa saja yang mereka butuhkan: buku-buku pelajaran, pengobatan, dan pemutaran film. Hal yang lebih penting adalah bahwa kedatangan penulis memang mereka harapkan dan sangat ditunggu.

Menggunakan ferry, diperlukan waktu 12 jam dari Sumatera daratan untuk bisa mencapai salah satu pulau di kepulauan Mentawai. Belum lagi, karena letaknya di pinggir Samudra Indonesia, gelombang yang harus dihadapi para penyebrang pun sangat ganas. Ombak tertinggi bisa mencapai 6 meter dalam cuaca baik. Kondisi ini banyak menciutkan siapa pun untuk berlayar ke pulau-pulau di Mentawai. Namun bagi sebagian turis asing, kawasan ini sebagai salah 
satu tujuan favorit untuk berselancar. Ditambah dengan alam indah yang dimiliki oleh Mentawai, turis yang berkunjung dapat melakukan kegiatan ekowisata, wisata budaya, dan wisata olah raga. Dalam sebulan, antara 10 hingga 15 orang wisatawan asing yang berkunjung ke wilayah ini, terutama untuk berselancar dan tinggal di resor-resor mewah dengan manajemen yang baik yang dikelola oleh pengusaha asing. Sedangkan kunjungan wisatawan lokal tidak dapat diprediksi karena sangat jarang. Padahal untuk penginapan, masyarakat Mentawai sangat senang untuk bisa menjamu para pendatang di rumah mereka sendiri.

Kepulauan Mentawai termasuk dalam provinsi Sumatera Barat. Selain pulau-pulau kecil, terdapat pula empat buah pulau besar yaitu Siberut, Sipora, Pagai Selatan, dan Pagai Utara. Siberut atau Si Berut, menurut bahasa asli daerah itu berarti Tikus. Mentawai atau Mentawei, berasal dari kata "si manteu" yang berarti "sakalangan" atau manusia. Pulau ini pertama kali ditemukan oleh seorang kapten Belanda. Menurut (Loeb, 1935), pada tahun 1692, sebuah peta dunia yang diterbitkan oleh pemerintah Prancis, menyertakan kepulauan ini dengan nama kepulauan Keberuntungan (Isle de la Fortune). Pada tahun 2009, Kepulauan Mentawai hanya memiliki empat kecamatan, yaitu Pagai Utara Selatan, Sipora, Siberut Selatan, dan Siberut Utara. Namun hingga tahun 2017 ini, jumlah kecamatan telah bertambah menjadi 10 buah, termasuk Sipora Utara, Pagai Selatan, Sikakap, Sipora Selatan, Siberut Selatan, Siberut Utara, Siberut Barat, Pagai Utara, Siberut Barat Daya, dan Siberut Tengah.

Penduduk asli Mentawai berasal dari Sumatera, yang menyebrang ke pulau Nias, bagian utara dari kepulauan Mentawai, lalu menyebrang ke pulau Siberut. Tercatat, pada tahun 1621 (Loeb, 1935), hanya pulau Siberut yang berpenghuni sebelum akhirnya para petualang ini menyebar ke pulau-pulau lain di sekitarnya. Anak-anak dari masyarakat adat, keluarga mereka, dan komunitasnya, umumnya terlihat memiliki kekurangan jika dibandingkan dengan standar masyarakat modern dan mereka dianggap perlu bantuan untuk bisa meningkatkan taraf hidup mereka (Borman \& Baber, 1998). Mayoritas dari penghuni kepulauan Mentawai ini adalah subsisten, yaitu memanfaatkan kekayaan hutan untuk menyambung hidup. Sisanya, bekerja di daratan Sumatera, menjadi nelayan, dan bercocok tanam. Sebagian kecil lain, bekerja pada sektor pariwisata di tanah mereka yang dioperasikan oleh orang-orang asing. Hasil dari pariwisata in pun belum banyak dirasakan oleh masyarakat Mentawai (Irzal, 2016). Salah satu indikasinya adalah tingkat kemiskinan. Menurut Biro Pusat Statistik, dari tahun 2009 sejumlah 13.233 orang dan hingga 2013 berjumlah 13.265 orang.

Lebih lanjut, masyarakat Mentawai kini, kian menyadari pentingnya pendidikan. Mereka membiarkan dan mendorong anakanak di kepulauan itu untuk mengenyam pendidikan formal yang oleh para generasi sebelumnya masih dianggap hal yang belum umum. Tanpa mereka sadari, sesungguhnya pendidikan formal dapat dianggap sebagai langkah-langkah menuju akulturasi. Anakanak yang mengenyam pendidikan, akan terbuka pikirannya sehingga mereka mau keluar dari mainstream masyarakat pendahulunya. Tapi bukan serta merta menyatakan bahwa dampak pendidikan akan tidak baik bagi anak-anak, masyarakat, dan lingkungan kepulauan Mentawai. Pendidikan yang dirancang baik, diharapkan bisa meningkatkan kualias hidup mereka. Masyarakat adat yang berpendidikan justeru akan lebih menguatkan posisi adat mereka. Pendidikan akan membuat mereka lebih berdaya. Mereka perlu menciptakan kearifan khas agar tidak punah. Salah satu syaratnya adalah dengan berubah, dengan masuk sekolah dan anak-anak akan menjadi agen perubahan bagi komunitasnya.

Meningkatkan taraf pendidikan masyarakat Mentawai, diharapkan bisa menjadi peluang untuk membukakan pikiran mereka dan menciptakan interdependensi Jurnal Sarwahita Vol. 14 No. 01 Tahun 2017 | 36 
kepada masyarakat luar yang saling menguntungkan dari berbagai aspek.

Salah satu aspek yang membuat masyarakat Mentawai masih tergantung pada masyarakat di luar wilayahnya adalah aspek transportasi. Pergerakan individu dan barang telah menciptakan industri transportasi. Maka jenis-jenis produk dan jasa transportasi kian hari kian bervariasi dan jumlahnya terus bertambah. Jarak, jumlah, frekuensi perjalanan menjadi bukan hambatan lagi.

Sistem transportasi di kepulauan Mentawai sesungguhnya sudah lama berjalan. Secara rutin transportasi laut dari Sumatera daratan ke pulau-pulau di gugusan kepulauan Mentawai berlangsung setiap minggunya. Namun secara ekonomis tidak terlalu menguntungkan pagi pengelola jasa angkutan laut yang beroperasi di sana. Tak banyak barang dan penumpang yang diangkut.

Sistem transportasi adalah respon dari kebutuhan untuk saling berhubungan satu sama lain yang terus meningkat antar dari individu maupun dengan masyarakat dan untuk memudahkan pergerakan barang komoditi sebagai bagian dari ekonomi nasional dan global (Tolley \& Turton, 2014).

Persoalan besar bagi sistem transportasi di Mentawai, kebutuhan akan transfortasi dari individu dan masyarakat tidak tumbuh dengan signifikan dengan pertumbuhan di daerah lain di Indonesia pada umumnya. Masyarakat Mentawai telah hidup lama sebagai masyarakat dependen. Mereka subsisten mencukupi kebutuhan sehari-harinya sehingga tak banyak kegiatan bernilai ekonomis yang dilakukan.

Belum tingginya kebutuhan transportasi pada masyarakat Mentawai, dampak dari kegiatan ekonomi yang tidak mengalami peningkatan dari masa ke masa. Tingginya ketergantungan masyarakat Mentawai pada tradisi leluhur bukan berarti mereka tak perlu maju. Buktinya, keinginan mereka untuk berubah cukup tinggi. Hal ini penting, dibandingkan dengan banyak suku-suku 37 | Jurnal Sarwahita Vol. 14 No. 01 Tahun 2017 terisolir lain yang sangat rentan terhadap sesuatu yang dari luar lingkungannya.

Namun demikian, sebagai kawasan yang unik, kepulauan Mentawai memiliki daya tarik sendiri bagi para wisatawan. Kegiatan pariwisata di kepulauan Mentawai bisa menjadi stimulus yang baik bagi perkembangan daerah itu. Saat ini, sejumlah situs internet telah menuliskan Mentawai sebagai salah satu tujuan berselancar yang terbaik selain pantai Pelabuhan Ratu di Jawa Barat.

Mentawai memiliki syarat untuk dijadikan sebagai pariwisata pulau atau kepulauan, baik dari segi alam maupun budaya masyarakat setempat. Pariwisata pulau dapat berperan dalam pengembangan ekonomi dan sosial suatu pulau (Conlin \& Baum, 1995). Keuntungan lainnya antara lain:

1. Memperoleh pendapatan

2. Menyediakan lapangan kerja, secara lokal/nasional/regional

3. Memperbaiki ekonomi lokal/regional

4. Menciptakan awareness tentang suatu kawasan

5. Mendukung konservasi lingkungan/masyarakat

6. Memberi sumbangan bagi pengembangan infrastruktur

7. Menciptakan citra internasional (Conlin \& Baum, 1995)

Pemberdayaan masyarakat lokal untuk bisa menjadi tuan rumah bagi wilayahnya, perlu diciptakan dan dilakukan secara berkelanjutan. Kekayaan budaya dan sumber daya alam bisa mereka gali sebagai modal untuk bisa berkembang dan maju tanpa harus kehilangan jati diri. Merka harus keluar dari sempitnya pola pikir seragam tentang nilai hidup.

Berada terus pada kubangan kesederhanaan pola pikir, membuat masyarakat Mentawai rentan pada kemiskinan dan kemiskinan rentan pada berbagai jenis penyakit. Masyarakat yang sakit adalah masyarakat yang tidak akan pernah bisa maju. 
Dampak lebih jauh, mereka akan menjadi sangat lemah dan tidak memiliki kekutan untuk bernegosiasi. Mereka akan selalu pada posisi yang tidak aman.

\section{B. Identifikasi Masalah}

Ada tiga kendala besar yang dihadapi oleh masyarakat adat Mentawai. Pertama, karena letaknya yang jauh dari daratan dan terpisah jauh dari pulau-pulau lainnya, masyarakat di kepulauan ini dapat digolongkan sebagai masyarakat terpencil. Karena letak geografis yang kurang menguntungkan, berdampak pada: (a) Mereka kurang bisa mengakses energi, karena mereka hanya bisa menikmati listrik pada malam hari itu pun dengan bantuan mesin diesel. (b) Mereka kurang bisa mengakses pendidikan tinggi, karena yang ada hanya sekolah dasar. Untuk bisa melanjutkan ke sekolah yang tingkatannya lebih tinggi, orang tua harus mengirimkan anak-anaknya ke Sumatera daratan seperti ke ibukota provinsi.

Kendala kedua, kepulauan Mentawai terletak pada lempengan Eurosia yang sepanjang tahun saling bergerak dan begeseran. Gejala alam ini, sewaktu-waktu dapat menimbulkan gempa bumi dan bahkan bencana tsunami. Hidup mereka selalu dalam ancaman bahaya.

$\begin{array}{ccr}\text { Kendala } & \text { ketiga, secara } & \text { historis, } \\ \text { masyarakat } & \text { Mentawai } & \text { seolah }\end{array}$
perkembangannya terhenti pada jaman batu. Mereka tak pernah berkesempatan memasuki jaman perunggu dan jaman-jaman lainnya dimana masyarakat melakukan kegiatan bercocok tanam maupun mengolah besi. Revolusi pertanian, apalagi revolusi informasi, sama sekali tak menyentuh mereka.

\section{Perumusan Masalah}

Dari identifikasi masalah di atas, penulis merumuskan permasalahannya sebagai berikut: Kegiatan baksi sosial apa saja yang bisa dilakukan di Desa Madobak dan Desa Muara Siberut? Selanjutnya, kegiatan pengabdian ini juga ingin menjawab dua pertanyaan berikut:
1. Bagaimana menumbuhkan minat baca dan meningkatkan pengetahuan guru, murid, dan masyarakat adat di Desa Madobak dan Desa Muara Siberut?

2. Bagaimana untuk meningkatkan softskill guru dan dapat memberikan alternatif metodologi pengajaran, dan proses belajar mengajar bagi guru dan murid pada Sekolah Dasar di Desa Madobak dan Desa Muara Siberut?

\section{Tujuan Kegiatan}

Kegiatan pengabdian ini bertujuan untuk mengadakan bakti sosial berupa pendirian Rumah Baca di Desa Madobak dan Desa Muara Siberut dan pelatihan softskill tentang science game untuk guru-guru sekolah dasar dan menengah di Pulau Siberut, kepulauan Mentawai.

\section{E. Manfaat Kegiatan}

Setidaknya ada tiga manfaat penting dari kegiatan pengabdian ini:

1. Lembaga fakultas dan universitas, agar bisa terjalin network sosial dengan pihakpihak luar kampus. Selain itu, untuk membangun pengalaman hebat di daerah yang penuh tantangan dengan masyarakatnya yang menarik. Selain itu, untuk melakukan benchmark agar Fakultas Ekonomi bisa berkiprah lebih banyak lagi pada kegiatan-kegaitan yang bersifat nasional dan internasional.

2. Khalayak sasaran, sebagai penyegaran dan inspirasi untuk membangun daerahnya dan meningkatkan kualitas hidup masyarakat yang lebih baik.

3. Tim pengabdi dan dosen lainnya, untuk meningkatkan wawasan, menjawab tantangan, menciptakan peluang, mendapatkan pengalaman, dan membangun rasa percaya diri. 


\section{TINJAUAN PUSTAKA \\ A. Masyarakat Adat}

Karoba (2007, p. 104) menuliskan bahwa masyarakat adat adalah kelompok masyarakat yang menjalani kehidupannya berdasarkan nilai-nilai, pandangan hidup, hukum, dan tatanan adat mereka yang khas dan unik. Masyarakat adat merujuk pada kondisi sosial, budaya dan ekonomi dari kelompok masyarakat yang menjadi warga negara dari sebuah negara-negara yang dirasa belum maju, ketinggalan jaman, telanjang, kolot, yang artinya belum modern.

Di Indonesia, suku-suku yang bisa dikategorikan sebagai masyarakat adat antara lain suku Anak Dalam di Jambi, Mentawai di kepulauan Mentawai, dan Baduy di Banten, Kampung Naga di Jawa Barat, Dayak di Kalimantan, dan Dani di Papua. Keberadaan suku-suku yang dianggap sebagai masyarakat adat, diakui dalam UU no. 24 tahun 2003 dengan syarat: Secara fisik ada, menyesuaikan diri dengan perkembangan jaman, dalam wilayah NKRI, dan berdasarkan undangundang yang berlaku.

Menurut Steni (2008), eksistensi masyarakat adat baru dinyatakan ada, pertama, jika masuk dalam konteks politik unifikasi hukum dan stabilitas negara. Kedua, hubungan masyarakat adat dengan tanah dan sumber daya alam yang kompleks dan menjadi bagian dari identitas mereka, dibatasi oleh sekurang-kurangnya tiga syarat:

1. Unsur masyarakat yang masih merasa terikat oleh tatanan hukum adatnya sebagai warga bersama suatu persekutuan hukum tertentu, yang mengakui dan menerapkan ketentuan-ketentuan persekutuan tersebut dalam kehidupannya sehari-hari.

2. Unsur wilayah, yaitu terdapatnya tanah ulayat tertentu yang menjadi lingkungan hidup para warga pesekutuan hukum tersebut dan tempatnya mengambil keperluan hidupnya sehari-hari.

39 | Jurnal Sarwahita Vol. 14 No. 01 Tahun 2017
3. Unsur hubungan antara masyarakat tersebut dan wilayahnya, yaitu adanya tatanan hukum adat mengenai pengurusan, penguasaan, dan penggunaan tanah ulayatnya yang masih berlaku dan ditaati oleh para warga persekutuan hukum tersebut.

Bahkan badan dunia PBB, turut mengakui keberadaan masyarakat adat. Sebelum menjadi ketetapan, sejumlah negara telah menyelesaikan draft untuk melindungi kelompok ini. Negara-negara itu adalah Belgia, Bolivia, Costa Rica, Kuba, Denmark, Republik Dominika, Ekuador, Estonia, Finlandia, Jerman, Yunani, Guatemala, Hongaria, Latvia, Nakaragua, Peru, Protugal, Slovenia, dan Spanyol. Draft ini dibuat berdasarkan rekomendasi Dewan Hak-hak Azasi Manusia tentang masyarakat Adat tanggal 29 Juni 2006. Selanjutnya, pada tanggal 7 September 2007, draft tersebut telah dijadikan resolusi PBB.

\section{B. Jaminan Hukum Pelayanan Pendidikan untuk Masyarakat Adat}

Pasal 14 Resolusi Sidang Umum PBB tanggal 7 September 2007 mengakui pentingnya pendidikan bagi masyarakat adat, yaitu:

Pertama, "Masyarakat adat berhak mendirikan dan mengendalikan sistem pendidikan dan kelembagaaan yang menyediakan pendidikan dalam bahasa mereka sendiri, dalam cara yang tepat bagi metode-metode dalam budaya mereka dalam hal mengajar dan belajar".

Kedua, "Individu anggota Masyarakat Adat, khususnya anak-anak, berhak untuk mendapatkan pendidikan negeri di segala tingkatan dan dalam semua bentuk tanpa ada diskriminasi".

Ketiga, "Negara patut, dalam kaitannya dengan Masyarakat Adat, mengambil langkah-langkah efektif, agar anggota masayrakat adat secara individual, khususnya anak-anak, termasuk mereka yang hidup di luar komunitas mereka, memiliki akses, di 
mana kalau memungkinakan, untuk mendpaatkan pendidikan dalam budaya mereka sendiri dan disediakan dalam bahasa mereka sendiri".

Sementara pasal 21 , ayat 1 , menegaskan tentang: "Masyarakat adat berhak, tanpa diskriminasi, atas peningkatan kondisi ekonomi dan sosial mereka, termasuk antar alain dalam bidang pendidikan, pekaryaan, pelatihan keuruan dan pelatihan ualng, perumahan, sanitasi, kesehatan, dan keamanan sosial".

\section{Wajib Belajar Sembilan Tahun dalam Sistem Pendidikan di Indonesia}

Wajib belajar sembilan tahun menjadi program wajib nasional yang juga berhembus di kepulauan Mentawai. Program ini dikembangkan melalui pendekatan politik dan sosio-kultural. Pendekatan politik memanfaatkan kekuatan dari pemerintah yang mewakili negara, swasta, dan kelompok masyarakat. Sedangkan pendekatan sosiokultural, menerapkan nilai budaya yang mengakar suatu masyarakat ke dalam sistem manajemen program wajib belajar.

Pada kasus pendidikan pada masyarakat adat di desa Madobak dan Muara Siberut, dua dari unsur di atas, yaitu pemerintah dan kelompok masyarakat, bekerja dengan baik. Pemerintah menyediakan bangunan fisik, masyarakat lokal menyiapkan ruangannya, dan tim voluntir sebagai kelompok masyarakat luar yang mengisi program.

Menurut pemancangan program wajib belajar pendidikan dasar sembilan tahun pada tahun 1994 akan sudah tuntas pada tahun 2003/2004 dengan Angka Partisipasi Kasar (APK) SMP mencapai 50\%. Namun akibat resesi multidimensi sejak tahun 1997, target ini diundur hingga 2008/2009. Namun demikian target kedua ini pun tetap belum bisa tercapai, apalagi di kepulauan Mentawai.

Salah satu langkah yang dibuat untuk mengantisipasi keterbatasan sjumlah daerah untuk mewujudkan program pendidikan dasar sembilan tahun adalah dengan mengembangkan SD-SMP Satu Atap. Pengembangan ini memanfaatkan dan menambah berbagai sumber daya yang ada. Hal ini tepat diterapkan pada daerah-daerah terpencil, terisolasi, dan terpencar-pencar guna memperluas dan meratakan layanan pendidikan dasar.

SD-SMP Satu Atap dikembangkan oleh Direktorat Pendidikan Lanjutan Pertama Direktorat Jenderal Manajemen Pendidikan Dasar dan Menengah. Sebagai tahap awal, memang hanya SD-SD negeri di daerah terpencil yang memenuhi syarat.

UUSPN no. 20 tahun 2003, bab IV ayat 3: "Warga negara di daerah terpencil atau terbelakang serta masyarakat adat yang terpencil berhak memperoleh pendidikan layanan khusus." Selanjutnya, undang-undang dan peraturan lain yang berlaku banyak memberi dukungan kepada masyarakat terpinggirkan (LSU Bina Insani, 2008), baik itu masyarakat miskin maupun masyarakat adat untuk memperoleh pendidikan, termasuk wajib belajar sembilan tahun.

\section{METODOLOGI}

\section{A. Khalayak Sasaran Antara}

Khalayak sasaran untuk kegiatan pengabdian masyarakat ini adalah penduduk di Desa Madobak dan Desa Muara Siberut, Kecamatan Siberut Selatan, Kabupaten Kepulauan Mentawai.

\section{B. Lokasi Kegiatan \\ 1. Muara Siberut}

Terletak di pantai timur Pulau Siberut dan masuk Kecamatan Siberut Selatan, di sini terhampar 7.500 hektar rawa bakau, hutan pantai, dan terumbu karang. Kawasan ini tidak saja bernilai ekonomis dari sisi perikanan dan ekowisata, tapi juga tempat pendidikan kelestarian alam dan riset ilmu pengetahuan.

\section{Desa Madobak}

Desa ini terletak di kawasan tenggara Siberut, di tepi Sungai Rereiket. Desa ini kendati terletak jauh di tengah hutan, 
namun sering menjadi pangkalan penelitian para ilmuwan berbagai bangsa. Potensi ekowisata dan antrowisata menjadi sumber pendapatan yang belum terangkat pada skala ekonomis.

\section{Metode Pelaksanaan}

1. Pengabdian Masyarakat

Kegiatan pengabdian masyarakat ini berupa pelayanan pada masyarakat dengan melakukan kegiatan yang belum pernah dilakukan sebelumnya oleh pihak manapun pada kawasan daerah yang akan dituju. Kegiatan ini bersifat bakti sosial. Tim akan bekerja sama dengan para volunteer yang terdiri dari sekelompok white collars yang gemar bertualang dan memiliki kepedulian terhadap lingkungan alam dan sosial.

Pra-kegiatan dilakukan dengan mempelajari karakteristik alam dan masyarakat Mentawai lewat buku-buku, surat kabar, dan artikel on line. Tim juga melakukan komunikasi dengan nara sumber yang ada di Pulau Siberut untuk mengetahui keinginan dan kebutuhan masyarakat, termasuk kondisi terkini daerah Mentawai. Kegiatan dilanjutkan dengan membuat proposal kegiatan, membuat anggaran, dan mencari pihak-pihak yang ingin terlibat dalam kegiatan sosial ini yang tujuannya untuk meringankan biaya pengadaan materi, transportasi, distribusi barang, dan dokumentasi.

\section{Rancangan Evaluasi}

Karena waktu pelaksanaan yang terbatas, maka evaluasi kegiatan langsung dilakukan begitu setiap kegiatan selesai diselenggarakan. Evaluasi ini akan melibatkan anggota tim internal dan para volunteer sendiri, dengan melakukan review dan diskusi. Masyarakat juga diminta untuk memberikan testimoni, opini, kritik, dan kesan mereka. Semua kegiatan akan didokumentasikan (foto dan video) sehingga dapat dijadikan bukti otentik pelaksanaan kegiatan.

\section{E. Perencanaan Dan Jadwal Kegiatan}

Kegiatan pengabdian ini dimulai pada bulan Maret dan bera di bawah.

Tabel 1. Jadwal kegiatan

\begin{tabular}{|c|l|l|}
\hline No. & Kegiatan & Waktu \\
\hline 1 & $\begin{array}{l}\text { Rapat koordinasi, riset pendahuluan, pengembangan } \\
\text { proposal, presentasi }\end{array}$ & Maret - April \\
\hline 2 & Penyiapan materi yang dibutuhkan & April \\
\hline 3 & Evaluasi sebelum kegiatan, penajaman kegiatan & Mei \\
\hline 4 & Pelaksanaan pengabdian masyarakat dan evaluasinya & $19-25$ Mei \\
\hline 5 & Laporan kegiatan, presentasi, revisi, penyerahan & Juli \\
\hline
\end{tabular}

\section{HASIL KEGIATAN}

\section{A. Potret Pendidikan Anak di Pulau Siberut, Kepulauan Mentawai}

Hingga Juni 2009, Jumlah anak pada kelompok usia 5-6 tahun di pulau Siberut adalah 3471. Dari angka tersebut, sekitar 2655 anak belum terdaftar untuk bersekolah, 780 anak masih bersekolah, dan 36 anak putus sekolah. Pada kelompok usia 7-12 tahun, jumlah anak yang belum terdaftar sekolah adalah 676 orang, sementara yang putus 41 | Jurnal Sarwahita Vol. 14 No. 01 Tahun 2017 sekolah mencapai 320 orang. Pada kelompok usia ini, sekitar 11176 anak masih tercatat aktif sebagai murid.

Hal mencolok terlihat pada kelompok usia di atas 25 tahun, sekitar 2240 tidak pernah bersekolah, sedangkan sekitar 27691 orang tidak sekolah lagi. Kelompok usia produktif ini dapat dibayangkan hidup tanpa pendidikan yang cukup. Tidak heran jika kondisi pulau Siberut tetap seperti sekarang ini karena tidak ada agen-agen perubahan yang dapat 
membawa kawasan ini ke arah yang lebih baik sesuai dengan tatanan masyarakat modern. Data tersebut di atas tentu berubah jauh pada tahun 2017.

Dari hasil observasi dan wawancara dengan sejumlah tokoh pada saat itu, dapat digali beberapa temua, Misalnya, minat anakanak di pulau Siberut untuk bersekolah sangat tinggi. Meskipun demikian, peran orang tua dan guru tak dapat diabaikan dalam menumbuhkan minat mereka bersekolah. Orang tua memiliki peran penting dalam mendorong minat siswa untuk bersekolah. Setidaknya sebatas menyuruh untuk sekolah, tetapi tanggung jawab tentang kebutuhan yang dibutuhkan oleh siswa untuk kebutuhan pengembangan diri dan pengembangan talentanya masih kurang karena faktor ekonomi.

Bahkan minat mereka bersekolah juga dipengaruhi oleh tayangan-tayangan televisi yang mereka tonton. TV dapat memberi pengaruh positif bagi masyarakat di kepulauan Mentawai. Sementara peran Pemda dan tetua adat tak cukup terlihat perannya.

Sementara itu, peran Pemda bersamasama dengan pihak sekolah, serta beberapa lembaga swadaya masyarakat senantiasa berusaha meningkatkan kualitas dan fasilitas pendidikan. Diharapkan membaiknya kualitas dan fasilitas pendidikan akan menambah minat anak untuk bersekolah.

Peran sekolah juga dianggap penting terutama dalam mendorong minat siswa untuk bersekolah. Sekolah berusaha mengangkat komite sekolah untuk membantu pendidikan (sebagai mitra sekolah) dan sekolah berupaya untuk membantu siswa, untuk pembayaran pendaftaran, biaya PBM atau yang berhubungan dengan kegiatan sekolah. Sekolah menanggung lagi biaya opeasioanl sekolah (BOS). Selain itu, Pemda bersamasama dengan pihak sekolah serta beberapa lembaga swadaya masyarakat senantiasa berusaha meningkatkan kualitas dan fasilitas pendidikan di desa Madobag. Diharapkan membaiknya kualitas dan fasilitas pendidikan akan menambah minat anak untuk bersekolah.
Sekolah-sekolah di pulau Siberut sebenarnya merupakan pusat kegiatan sosial dari masyarakat desa. Mestinya hal ini akan menarik minat masyarakat sekitar untuk bersekolah. Jika masih terdapat anak-anak yang tidak bersekolah, mungkin karena terdapat keterbatasan sosialisasi pendidikan di masyarakat yang lebih terpencil.

Pemerintah membantu sekolah dalam melakukan kegiatan sekolah, pengadaan buku, prasarana dan sarana yang mendukung, peningkatan mutu, pemberian bantuan makananan tambahan, beasiswa, bantuan siswa tidak mampu. Perhatian untuk sektor pendidikan telah dianggarkan lewat BOS (Bantuan Operasional Sekolah). Dana dialokasikan untuk operasional sekolah walaupun masih terkendala prosedural administrasi. Selain itu, pemerintah daerah telah mengusulkan program penggunaan BUMEN (Budaya Alam Mentawai) agar dapat ditetapkan sebagai muatan lokal di sekolah seperti misalnya hal-hal yang menjurus pada kegiatan ritual. Pemangku adat tidak terlalu berperan dalam hal ini. Fungsi pemangku adat lebih pada hal-hal ritual.

Khususnya di Desa Madobag, hingga Juni 2009, sekolah di sana baru memiliki kelas sampai kelas VII saja. Kelas di wilayah Madobag seperti standar SD pada umumnya, yaitu hingga kelas VI. Karena pemerintah telah memprogramkan WAJAR (wajib belajar) sembilan tahun, kelak jika semua pihak telah siap, kelas yang tersedia akan disediakan hingga kelas IX.

Karena alasan-alasan tertentu Sistem sekolah satu atap seperti yang ada di SD Madobag ini sebenarnya hal yang baru. Sebelumnya belum ada kelas VII dan SD hanya sampai kelas VI. Penambahan kelas menjadi kelas VII sebenarnya merupakan persiapan untuk membentuk sekolah menengah pertama. Kelas VII sebenarnya merupakan pengembangan dari SD yang telah ada. Sebenarnya sampai kelas VII merupakan suatu peningkatan dari kondisi sebelumnya. Sepengetahuan saya, SMP telah direncanakan untuk lanjutan SD Madobag dan tinggal

Jurnal Sarwahita Vol. 14 No. 01 Tahun 2017 | 42 
menunggu adanya siswa yang naik ke kelas VII.

Tergantung kebutuhan dan jumlah siswa yang ada serta kesediaan masyarakat dan dana yang tersedia. Sarana prinsipil tidak ada masalah. Saat ini hanya menunggu siswa kelas VII naik ke kelas lebih lanjut. Karena SMP baru (ada sejak) dua tahun (lalu). Sepertinya tidak ada masalah kecuali menuggu siswa.

Upaya dari pemerintah daerah untuk menambah kelas hingga lengkap menjadi sembilan kelas. Hal ini tergantung usul dari desa dan sekolah, sesuai dengan kebutuhan yang berkesinambungan. Saat ini rencana tersebut telah ada dan akan dilaksanakan jika siswa telah ada, yaitu siswa kelas VII yang naik kelas ke kelas VIII dan seterusnya.

Jika ada siswa yang ingin melanjutkan ke kelas lanjutan, sementara kelas yang dimaksud tidak tersedia, solusinya adalah dengan mendaftar ke sekolah di Muara Siberut. Pemerintah akan membantu siswa dari pelosok kepulauan yang berminat melanjutkan sekolah setelah dilakukan pendataan dan didukung oleh orang tua.

Hal-hal yang menjadikan sekolahsekolah di pulau menjadi unik dibandingkan sekolah-sekolah lain yang ada di daerah lain, misalnya, karena sering menjadi objek penelitian dari para peneliti baik mereka yang datang dari daerah lain di Indonesia, maupun peneliti dari luar negeri. Berkat melakukan penelitian di Mentawai, mereka sekarang sudah berhasil mendapat gelar doktor bahkan professor.

Hal-hal yang menjadi prioritas untuk memperbaiki sistem pendidikan di kawaasan ini adalah dengan meningkatkan jumlah dan kualitas tenaga pendidik, sarana, prasarana, dan mutu pendidikan. Bertambahnya jumlah murid di setiap sekolah dapat menjadi alasan untuk mengajukan penambahan jumlah tenaga penangajar kepada pemerintah. Apalagi jika jumlah kelas juga bertambah. Sedangkan untuk meningkatkan kualitas tenaga pengajar, dilakukan dengan memberikan motivasi kepada mereka. Motivasi ini penting agar para guru dapat lebih bertanggung jawab terhadap profesi mereka dalam mencerdaskan anakanak bangsa di pulau Siberut.

Selain itu, perlu juga memikirkan bagaimana menciptakan jaringan pendukung finansial. Selama ini, kendala utama bagi peningkatan sarana dan prasarana pendidikan di pulau Siberut adalah dana. Mestinya pemerintah setempat atau pengelola sekolah memiliki inisiatif atau alternatif sumber dana mandiri, terlepas dari alokasi dana pemerintah.

Sementara itu, penggunaan materi pengajaran yang lebih mengakar pada keadaan sosial dan budaya Mentawai dapat menjadi salah satu faktor yang dapat menyejajarkan kearifan lokal dengan pendidikan modern. Inilah kearifan akulturasi yang dapat menjunjung manusia Mentawai seutuhnya sekaligus meningkatkan taraf hidup.

\section{B. Kegiatan Pengabdian Masyarakat \\ 1. Pendirian Rumah Baca}

Berdasarkan hasil analisis kebutuhan di Pulau Siberut, perpustakaan adalah salah satu hal yang dibutuhkan oleh masyarakat di desa Madobak. Anak-anak dan masyarakat adat Mentawai memerlukan bantuan bagaimana mendirikan perpustakaan itu dan bagaimana melengkapinya dengan buku-buku yang dibutuhkan, seperti buku-buku pelajaran dan bacaan populer yang bermanfaat untuk meningkatkan kualitas hidup mereka.

Idenya adalah pendirian Rumah Baca atau Rumba. Untuk mewujudkan ide ini masyarakatkan setempat memanfaatkan ruang perpustakaan SD dan SMP negeri satu atap Desa Madobag yang berukuran 6x8 $\mathrm{m}^{2}$. Kegiatan ini berlangsung dari tanggal 20-23 Mei. Meskipun awalnya Rumah Baca ini hanya akan didirikan di satu lokasi, namun karena permintaan dari lokasi lain, maka didirikan di dua tempat yang berbeda. Dua Rumah Baca dibangun masing-masing berlokasi di Desa Madobak dan Desa Muara Siberut, Kecamatan Siberut Selatan, Kabupaten Kepulauan Mentawai. 
Sejumlah guru dan anggota masyarakat menunjukkan ketertarikan dengan terlibat langsung dalam pendirian Rumah Baca ini. Mereka antusias aktif secara gotong royong menyediakan tempat, ruangan dan rak. Sementara para volunteer dari Jakarta berperan dalam menggalang buku dari berbagai sumber dan sekaligus melatih tenaga pengelola untuk Rumah Baca ini. Konsep manajemen Rumah Baca ini adalah perpustakaan umum. Semua warga desa, dari dewasa sampai anak-anak, dapat memanfaatkan rumba sebagai hutan ilmu untuk ditebang tanpa takut habis.

Pendirian Rumah Baca ini secara total menghabiskan Rp 15,198,591. Uang dikumpulakn dari donatur yang sukarela menymbang. Berikut adalah detail biayabiayanya. Selain itu, ada sebagian buku yang dibeli setelah kegiatan selesai dikarenakan masih adanya donasi yang masuk meskipun kegiatan telah selesai.

\section{Pelatihan Softskill untuk Guru dan Pendidikan Sains untuk Murid}

Guru dan murid memerlukan alternatif metode belajar mengajar. Untuk menjawab masalah ini, tim menyelenggaraan pelatihan science game kepada para guru dan murid sekolah dasar. Science game adalah permainan ilmiah tentang ilmu pengetahuan alam dengan perangkat yang sangat murah dan mudah ditemukan di sekitar rumah tinggal murid namun dapat memberikan pemahaman yang luar biasa tentang berbagai gejala alam.

\section{Pelaksanaan Pelatihan Softskill untuk Guru}

Satu hari menjelang kegiatan pendidikan sains bagi murid-murid sekolah dasar, tim melakukan acara perkenalan dengan para guru lokal yang kelak akan dijadikan mentor untuk mendampingi Pos C Roket Air. Mentor lokal diajari cara merakit peluncur roket model $\mathrm{H}$ dan L, sekaligus mendemonstrasikannya secara prinsip.

Selain itu, tim dan para guru menyiapkan lokasi yang akan digunakan untuk pembuatan dan peluncuran roket untuk besok harinya.
Pada kesempatan ini pula, tim berdiskusi dengan para guru tentang metode dan teknik pengajaran yang paling mudah dicerna bagi murid-murid sekolah dasar yang masih duduk pada di bangku kelas V dan VI. Setelah pelatihan softskill selesai, para peserta pelatihan ini dilibatkan dalam permainan science game yang pesertanya adalah muridmurid Sekolah Dasar.

\section{Pelaksanaan Pendidikan Science Game untuk Murid}

Proses kegiatan sains melibatkan sekitar 120 murid SD selama kira-kira tiga jam. Ada sekitar 12 orang tenaga pengajar yang tergerak untuk melakukan kegiatan ini. Sementara jumlah murid SD, terdiri dari:

Kelas 1 - 79 anak

Kelas 2 - 47 anak

Kelas 3 - 40 anak

Kelas 4 - 36 anak

Kelas 5 - 29 anak

Kelas 6 - 23 anak

Kelas 7 - 29 anak

Kegiatan diawali dengan permainan pembuka dengan membentuk sebuah kelompok besar. Selanjutnya kelompok besar dipecah menjadi beberapa kelompok kecil. Setiap kelompok kecil mendapatkan satu jenis permaianan. Pada selang waktu tertentu, masing-masing kelompok akan bergeser ke topik kelompok lain. Total kegiatan berlangsung selama 3 jam.

Pada bagian akhir, siswa diberikan kegiatan yang akan mengunci seluruh pemahaman yang mereka dapatkan sejak 3 jam sebelumnya. Proses kegiatan sains ini dilengkapi dengan manual penyelenggaraan kegiatan. Materi tersebut di bawah ini akan diberikan dalam bentuk permainan. Pelaksanaan kegiatan ini mempertimbangkan dengan hanya menggunakan bahan-bahan yang mudah ditemukan di desa mereka

Jurnal Sarwahita Vol. 14 No. 01 Tahun 2017 | 44 
Murid-murid diajak memahami prinsip aerodinamika benda melalui percobaan. Mereka akan membuat dan menerbangkan beberapa jenis roket sederhana dan membuktikan, mana jenis roket yang mampu melontar lebih baik, stabil, dan lebih jauh. Secara tidak langsung, murid-murid diberikan pemahaman mengenai proses kerja panah berburu atau tombak yang biasa dipakai oleh nenek moyang mereka.

Masyarakat Mentawai akrab dengan panah dan busur di tengah budaya berburu lokal. Namun mereka sepertinya tidak akrab dengan Hukum Newton. Permainan, atau lebih tepatnya pelajaran ini akan menjelaskan ketiga prinsip Newton pada panah. Lebih daripada panah, tim mengajak murid-murid melihat lebih jauh prinsip kerja Newton pada benda yang serupa yaitu roket air.

Hukum pertama Newton dalam bahasa sehari-hari adalah benda bergeming sampai didorong, dengan kata lain, semua benda bergerak lurus beraturan hingga terganggu gaya lain. Hukum ini berlaku pada roket atau panah yang siap-luncur.

Hukum kedua Newton, adalah benda melesat sekuat dorongan atau $\mathrm{F}=$ m.a. Hukum ini berlaku ketika roket atau panah dilepaskan dari landasan. Hukum ketiga Newton, benda bergerak sampai ditahan sekuat dorong pula atau aksi sama dengan reaksi atau F1 = F2. Prinsip ini berlaku ketika roket berhenti lambat-laun akibat dihambat sama kuat oleh tekanan udara, dan akhirnya tergolek bergeming lagi di tanah.

Adapun jadwal kegiatan, peralatan, dan bahan yang dibutuhkan untuk membuat kegiatan Pos Pelatihan Sains Luar Ruangan roket air adalah sebagai berikut: rafia untuk tali parasut, gunting, sirip, karet gelang, plastik bekas, stopwatch, pasak kayu, peluit, lem PVC, dan pompa tangan.

Kamis, 21 Mei, kegiatan science game untuk murid dilaksanakan. Diawali dengan ice breaking. Murid-murid diminta membuat lingkaran kecil. Masing-masing diajak berhitung mulai 1 sampai 4 dan berulang kembali ke hitungan 1 hingga 4 untuk murid kelima dan seterusnya. Setiap murid berkumpul berdasarkan angka masingmasing. Misalnya, murid yang kena hitungan angka 1, berkumpul dengan murid yang terkena hitungan angka 1 lainnya. Demikian juga untuk murid-murid yang terkena hitungan angka 2, 3, dan 4. Kemudian, tiap kelompok diberi nama: Nusa, Bangsa, Bahasa, dan Bumi. Setelah itu, permainan untuk memecah kekakuan dimulai.

Pada Kelompok Bumi diajarkan cara merakit peluncur roket dan mekanisme kerjanya. Kelompok ini bertugas sebagai teknisi peluncur roket, mulai dari memasang roket ke laras peluncur, sampai penekanan pelatuk. Briefing ini dilakukan di ruang terbuka oleh tim.

Pada kelompok Nusa, Bangsa, dan Bahasa diajarkan cara merakit roket air. Tugas kelompok ini membuat roket air yang paling lama jatuh ke tanah. Karena nantinya akan ada pertandingan, untuk memenangi pertandingan itu, mereka harus memahami 3 Hukum Newton yang berlaku pada pembuatan parasut, moncong, badan, dan penyemprot (nozzle) roket. Briefing ini dilakukan di ruang tertutup, di dalam kelas. Papan tulis sangat membantu memberikan ilustrasi kerja dan menjelaskan aturan main pertandingan.

Setelah penjelasan, acara perakitan roket dimulai. Murid-murid hanya diberi waktu terbatas untuk merakit. Selesai tidak selesai, roket harus dibawa ke luar untuk pertandingan. Kelompok Bumi, dipecah ke dalam tiga kelompok. Mereka masuk ke kelompok Nusa, Bangsa, dan Bahasa sebagai juru tembak.

Berikutnya adalah pertandingan roket air. Pertandingan ini menggunakan peluncur model $\mathrm{H}$ dan model $\mathrm{L}$ yang ditempatkan di lapangan terbuka. Setiap kelompok mendapat kesempatan menembakkan roket pada masing-masing peluncur sebanyak 3 kali (total enam tembakan per kelompok atau 18 salvo roket air). Apabila roket sampai menyangkut di pohon, maka tidak ada pengganti roket dan perhitungan waktu jatuh roket digugurkan. 
Salah seorang dari tim yang menjadi mentor, bertugas sebagai wasit peniup peluit, satu orang lagi menjadi pencatat waktu. Sedangkan mentor lokal berperan sebagai penulis skor. Selama prosesi peluncuran, regu Nusa, Bangsa, dan Bahasa boleh memprovokasi dengan yel-yel. Setiap pompaan dihitung ramai-ramai oleh kelompoknya. Hitungan mundur (countdown) juga dilakukan oleh kelompok masingmasing.

Aturan penghitungan: setiap waktu dijumlahkan, bukan dirata-rata. Jadi peraih total waktu jatuh terpanjang langsung dinyatakan sebagai pemenang.

\section{Percobaan Gempa Bumi dan Bangunan Ramah Gempa}

Kegiatan ini terinspirasi dari kenyataan bahwa Indonesia merupakan negara yang rawan gempa. Memahami bagaimana gempa terjadi dan bagaimana bangunan dirancang agar ramah terhadap gempa merupakan tujuan dari percobaan ini. Mengambil ide dari kearifan lokal dan bahan-bahan sederhana yang ada di sekitar, anak-anak diharapkan dapat mengasosiakan teori-teori mengenai gempa tektonik termasuk cara menyikapinya dalam kehidupan sehari-hari, dengan cara yang menyenangkan.

Dalam percobaan ini akan disimulasikan pergerakan "lempeng tektonik" yang dapat saling mendekati dan menjauhi, serta efek yang ditimbulkannya pada permukaan bumi. Lempeng tektonik disimulasikan oleh kertas yang akan ditutupi dengan tanah dengan ketebalan sekitar $1 \mathrm{~cm}$, untuk menggambarkan permukaan bumi. "Lempeng Tektonik" ini akan didorong dan ditarik dari arah yang berlawanan, sehingga anak-anak dapat mengamati apa yang terjadi pada permukaan bumi, jika pergerakan lempeng terjadi.

Untuk membuatnya lebih menarik, murid-murid diajak berkompetisi untuk membangun bangunan ramah gempa, yang didefinisikan dalam percobaan ini sebagai bangunan yang paling lama atau masih dapat bertahan di atas permukaan tanah setelah "lempeng tektonik" digerakkan. Pemahaman akan dilakukan pada akhir percobaan dengan menghubungkan prinsip bangunan ramah gempa yang bertujuan meminimalkan kemungkinan runtuhnya struktur bangunan dan jatuhnya korban jiwa, dengan konsep bangunan tradisional ramah gempa yang telah dikenal oleh nenek moyang kita, sejak ribuan tahun yang lalu.

Permainan ini menggabungkan tiga kegiatan olah raga sekaligus: lompat harimau, menembak/membidik sasaran dan berlari: dilengkapi dengan pertanyaan singkat mengenai pemahaman pengetahuan umum, menjadikan permainan Trilomba Mini ini sebagai aktivitas pelatihan kemampuan jasmani dan intelektual yang lengkap bagi anak-anak.

Untuk melakukan permainan, kelas dibagi ke dalam kelompok-kelompok kecil yang saling berkompetisi. Setiap kelompok bersaing mendapatkan waktu tercepat untuk secara berurutan melakukan kegiatan lompat harimau bergantian, menjawab pertanyaan singkat mengenai pengetahuan umum, melempar bola tenis tepat pada sasaran, dan berlari secepatnya kembali ke titik awal.

Saat melakukan lompat harimau, muridmurid belajar untuk mengukur kekuatan masing-masing. Kekuatan dan kesigapan diperlukan dalam permainan ini agar tidak ada yang cidera. Saat menembak sasaran, muridmurid membutuhkan ketepatan dalam memperkirakan jarak sasaran. Ini yang sering disebut sebagai kecerdasan ruang. Kerja sama dan strategi yang baik dalam pembagian tugas anggota kelompok juga mengajarkan muridmurid mengenai dinamika berorganisasi dan pentingnya mengalokasikan pekerjaan berdasarkan kemampuan untuk mencapai tujuan bersama.

\section{KESIMPULAN}

Dari kegiatan pengabdian masyarakat ini dapat ditarik beberapa kesimpulan. Kegiatan pengabdian masyarakat ini bertujuan untuk mendirikan rumah baca berupa perpustakaan dan pemberian pelatihan soft-skill kepada guru-guru SD. Berdasarkan pengamatan Jurnal Sarwahita Vol. 14 No. 01 Tahun 2017| 46 
penulis, pendirian rumah baca di pulau Siberut kepulauan Mentawai mendapatkan sambutan positif dari masyarakat, guru - guru dan pemda setempat, dari hal ini dapat disimpulkan bahwa minat masyarakat untuk membaca buku dan menggali ilmu sangat tinggi.

Saran-saran yang dapat diberikan untuk kegiatan pengabdian masyarakat semacam ini adalah sebagai berikut: Pertama, karena jumlah anak yang tidak bersekolah dan putus sekolah karena alasan ekonomi keluarga sangat tinggi, sementara minat mereka untuk sekolah sangat tinggi, maka diperlukan upaya nyata dari pemerintah pusat, pemerintah daerah maupun pihak swasta untuk memberdayakan kemampuan ekonomi keluarga di pulau Siberut kepulauan Mentawai. Seperti misalnya membuka lapangan usaha dan memberikan keterampilan-keterampilan khusus. Kedua, anggaran pembangunan di pulau Siberut kepulauan Mentawai agar lebih ditingkatkan oleh pemerintah, hal ini agar tujuan mewujudkan masyarakat adil dan makmur dapat tercapai.

\section{DAFTAR PUSTAKA}

Asdhiana, I Made. (2016). Mentawai, salah satu suku tertua di dunia. Retrieved from Kompas.com website: http://travel.kompas.com/read/2016/1 0/27/071000427/mentawai.salah.satu. suku.tertua.di.dunia

Borman, Kathryn M, \& Baber, M Yvette. (1998). Ethnic diversity in communities and schools: Recognizing and building on strengths: Greenwood Publishing Group.

Candra, Sapto Andika, \& Puspita, Ratna. (2017). Pembangunan infrastruktur Mentawai mendesak. Retrieved from Kompas.com website: http://nasional.republika.co.id/berita/n asional/daerah/17/08/22/ov38xb428pembangunan-infrastrukturmentawai-mendesak

Conlin, Michael V, \& Baum, Tom. (1995). Island tourism: Management principles and practice: Wiley.
Irzal, Muhammad. (2016). Dampak pariwisata Mentawai belum dinikmati masyarakat. Retrieved from Kompas.com website: http://travel.kompas.com/read/2016/0 4/07/213400027/Dampak.Pariwisata. Mentawai.Belum.Dinikmati.Masyara kat

Karoba, Sem. (2007). Deklarasi Perserikatan Bangsa-Bangsa Tentang Hak-Hak Asasi Masyarakat Adat: Cet. 1. Yogyakarta: Galangpress. hlm.

Loeb, Edwin Meyer. (1935). Sumatra: its history and people (Vol. 3): Inst. f. Völkerkunde d. Univ. Wien.

Steni, Bernandinus. (2008). Politik Pengakuan IdentitasMasyarakat Adat: Dari Hindia Belanda Hingga Indonesia Merdeka. Jurnal Jentera, 18.

Tolley, Rodney, \& Turton, Brian John. (2014). Transport systems, policy and planning: a geographical approach: Routledge. 